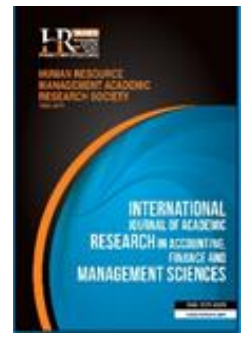

International Journal of Academic Research in Accounting, Finance and Management Sciences

Vol. 8, No.4, October 2018, pp. 144-152

E-ISSN: 2225-8329, P-ISSN: 2308-0337

(C) 2018 HRMARS

www.hrmars.com

To cite this article: Alkhatib, A.A., Abdul-Jabbar, H., Munusamy Marimuthu, M. (2018). The Effects of Deterrence Factors on Income Tax Evasion among Palestinian SMEs, International Journal of Academic Research in Accounting, Finance and Management Sciences 8 (4): 144-152.

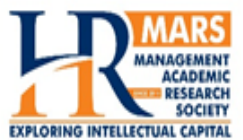

http://dx.doi.org/10.6007/IJARAFMS/v8-i4/5471 (DOI: 10.6007/IJARAFMS/v8-i4/5471)

\title{
The Effects of Deterrence Factors on Income Tax Evasion among Palestinian SMEs
}

\section{Amjad Abdallah Alkhatib ${ }^{1}$, Hijattulah Abdul-Jabbar², Munusamy Marimuthu ${ }^{3}$}

\author{
${ }^{1}$ Tunku Puteri Intan Safinaz School of Accountancy, Universiti Utara Malaysia, \\ ${ }^{1}$ E-mail: amjad@paluniv.edu.ps, (Corresponding author) \\ ${ }^{2}$ Tunku Puteri Intan Safinaz School of Accountancy, Universiti Utara Malaysia, 2E-mail: hijat@uum.edu.my \\ ${ }^{3}$ Tunku Puteri Intan Safinaz School of Accountancy, Universiti Utara Malaysia, ${ }^{3}$ E-mail: munusamy@uum.edu.my
}

\begin{abstract}
Tax evasion remains an issue confronting most policy makers worldwide. Palestine, as an evolving developing country highly depends on tax revenue and funds from international aids to finance the country's growth plan. The current study aims at examining relationships between probability of detection, tax penalty, tax rate and income tax evasion by applying the Deterrence Theory. A proportionate sampling technique was employed to collect data for the study through the use of questionnaires. The total number of useable questionnaires collected for analysis was 184. The collected data were analysed using the Partial Least Square (PLS). The result of analysed data shows that probability of detection and tax penalty were found to be negatively significant, while tax rate was positively significant in relation to income tax evasion. The implication of the findings of the current study is that income tax administration effectiveness can maximize tax collections and discourage tax evasion.
\end{abstract}

Key words Probability of Detection, Tax Penalty, Tax Rate, Tax Evasion, Deterrence Theory

Received: 04 Dec 2018 (c) The Authors 2018

Revised: 23 Feb 2019 Published by Human Resource Management Academic Research Society (www.hrmars.com)

Accepted: 27 Feb 2019 This article is published under the Creative Commons Attribution (CC BY 4.0) license. Anyone may 28 Feb 2019 reproduce, distribute, translate and create derivative works of this article (for both commercial and noncommercial purposes), subject to full attribution to the original publication and authors. The full terms of this license may be seen at: http://creativecommons.org/licences/by/4.0/legalcode

\section{Introduction}

Tax revenue is globally regarded as the oldest means of generating funds for sustainability of governments and most economies rely on taxation in order to meet up their expenditure needs (Kira, 2017; Okauru, 2012). This implies that taxation has been the most realistic means of generating revenue by governments for funding their development projects (Tanzi and Zee, 2001). Torgler (2005) revealed that numerous factors influence the value of tax revenue generated by the government. One of the vital factors is the willingness of taxpayers to comply with the provisions of tax laws. McGee et al. (2008) further stressed that $100 \%$ compliance with tax regulations is not attainable in any country. The lack of compliance to the provisions of tax laws indicates that taxpayers are evading tax (Kirchler, 2007). In this regard, Franzoni (2000) asserted that tax evasion is the commonest and most critical challenge of tax administration. Tax evasion is any intentional unlawful behaviour of cutting down tax responsibility by the taxpayers (Alm et al., 2016). Tax evasion has major implication on tax revenue loss for the government (Bott et al., 2017). Similarly, Schneider and Enste (2000) emphasised that revenue losses decreases governments' ability to provide public services, therefore obstructing economic development. 
Palestine, which is a developing country relies heavily on tax revenue and international aids to fund its nation's growth and development (Alkhatib and Abdul-Jabbar, 2017). In Palestine, the administration of income tax is marked by a high level of tax evasion (Rahhal, 2017). In recent times, the Coalition for Integrity and Accountability in Palestine estimated that USD 500 million was the annual loss from the Palestinian treasury due to tax evasion (Coalition for Accountability and Integrity, 2018). With regards to income tax evasion, the Finance Minister emphasized that $80 \%$ of society accounts for only $10 \%$ of the income tax (Bishara, 2015). Even though, SMEs in Palestine make up 99\% of business taxpayers, they accounted for only $30 \%$ of the income tax revenues. This is far less than what is expected to be generated from the SMEs (Fallah, 2014). This suggests a high level of engagement in tax evasion by several SMEs (Sabri, 2010). With the current level of tax evasion in Palestine, there is need for an in-depth examination of the important economic factors that could influence tax evasion in a bid to develop policies to increase revenue for the government.

\section{Literature Review and Hypothesis Development}

\subsection{Probability of Detection and Tax Evasion}

Probability of detection implies the likelihood of detecting tax evasion behaviour by the tax authorities through the use of its enforcement tools (Alstadsæter et al., 2017; Chau and Leung, 2009). According to the economic model, taxpayers attempt to obtain maximum benefits out of their compliance decision by comparing the benefits of accomplished tax evasion against the cost of detection and punishment. Allingham and Sandmo (1972) therefore affirmed that when the probability of detection is high, more proportion of income will mostly be declared. Base on the assumption of risk-averse taxpayers implies that an increase in the frequency of audit would decreases tax evasion (Abdixhiku, 2013; Almunia and Lopez-Rodriguez, 2018). Many existing studies found the correlation between the probability of detection and tax evasion to be negative (Almunia and Lopez-Rodriguez, 2018; Ayers et al., 2015; Bott et al., 2017; Slemrod et al., 2001).

In contrary, the outcome of the study in Israel by Ariel (2012) found that the effect of perceived probability of detection along with apprehension on tax evasion to be insignificant. This is in line with the findings of another empirical study by Alm and McKee (2006), which also established the insignificant effect of audits. Therefore, it can be concluded that most of the studies reported a negative influence of probability of detection, while a few of the existing studies found that it has no significant influence. Thus, the current study proposes the followings:

H1: There is a negative relationship between probability of detection and tax evasion.

\subsection{Tax Penalty and Tax Evasion}

Tax penalty implies how strict the punishment is in terms of fines and imprisonment linked to the detection of tax evasion (Efebera et al., 2004). When a taxpayer is expected to file an income or carry out tax a return then fails to comply in time, tax penalties can be charged on such a person for late filing (Oladipupo and Obazee, 2016). Allingham and Sandmo (1972) reported that a declaration of larger income can be achieved through the increase in the probability of detection and tax penalties. Similarly, Chau and Leung (2009) affirmed that tax evasion could be reduced by raising the tax penalties associated with it. In a similar study, Feld and Frey (2006) showed that the existence of a severe tax penalty will curtail a number of practices of tax evasion. In the same vein, Hasseldine et al. (2007) also confirms that the severity of criminal sanctions is significantly associated with tax evasion.

On the other hand, numerous studies found no support for the deterring effects of tax penalties. Ali et al. (2001) found that tax penalties have no impact on tax evasion by analysing tax evasion act of American taxpayers. While, Oladipupo and Obazee (2016) found that tax penalty had an insignificant negative impact on tax evasion amongst SMEs in Nigeria. Whereas, contrary to the findings of the earlier reported studies Fjeldstad and Semboja (2001) conducted a similar study in Tanzania and found that it had a positive impact. The previous study also acknowledged that oppressive tax imposition and harassment of taxpayers has led to more resistance by pay taxes. Based on the findings of the literature on tax penalties as discussed above, it can be concluded that most of the existing studies reported that tax penalties have a 
negative influence. Only a few studies reported that the influence of penalties is positive and insignificant. Thus, the following proposition is made:

H2: There is a negative relationship between tax penalty and tax evasion.

\subsection{Tax Rate and Tax Evasion}

Tax rate is regarded as the quantity of tax payable by a taxpayer in relation to the taxable item in line with the principles of taxation (Mansor and Gurama, 2016). Devos (2007) described tax rate as a vital tax structure variable associated with the perception of fairness of the tax system. The Deterrence Theory forecasted that rising tax rate reduces tax evasion (Allingham and Sandmo, 1972). In contrast to the theory, numerous studies from both developed and developing countries have proven that tax rates are positively associated with tax evasion (Dlamini, 2017; Guldana, 2013; Malkawi and Haloush, 2008; Martinez-Vazquez and Rider, 2005). Taxpayers consider a high tax rate as an excuse for evading taxes hence; underreport their proceeds and earnings to the tax authorities. Rahhal (2017) examined changes in tax rates and the effect on tax evasion in Palestine. The study found that the effect of tax rate on tax evasion was positive. In a more recent study by Ottone et al. (2018) assessed two countries (Sweden and Italy) characterized by high tax rates and found the relationship to be positive.

In contrary to the findings of the earlier studies reported, a few studies also reported a negative relationship between tax rates and tax evasion. These studies includes Adebisi and Gbegi (2013), Nzaro et al. (2013) and Olowookere and Fasina (2013), their studies reported a negative relationship between tax rate and tax evasion. It can be concluded that most studies found a significant and positive effect of tax rate on tax evasion, whereas few studies reported a negative effect on tax evasion. Hence, the following hypothesis is derived:

H3: There is a positive relationship between tax rate and tax evasion.

\section{Research framework}

The research model, presented in Figure 1 below was developed based on the economic Deterrence Theory. The theory signifies that tax behaviour is influenced by the probability of detection, tax penalty and tax rates. Base on the Deterrence Theory, the variation in crime propensity between individuals is dependent on the expected benefit or cost rather than the difference in motivation to commit crime. This implies that the theory asserts that an individual is rational in his/her decision and only aims at maximizing expected utility.

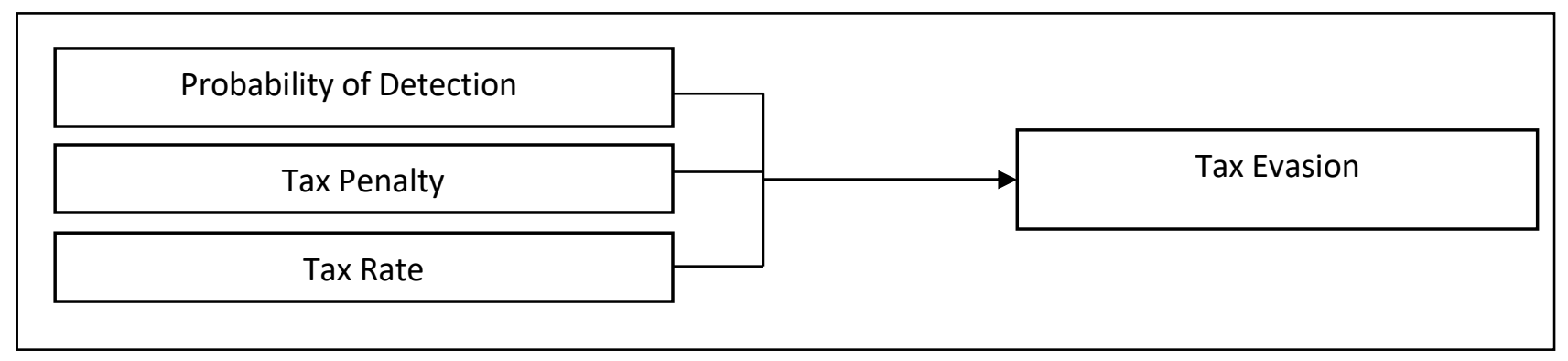

Figure 1. Research Model

\section{Methodology of research}

\subsection{Data Collection}

Data for the present study was collected at business entity level, which served as the unit of analysis for the present study. The data were obtained from 500 SMEs registered under the Federation of Palestinian Chambers of Commerce and Industry. A proportionate random sampling technique was used to distribute questionnaires among selected respondents which were the owners/managers of SMEs. The questionnaires were distributed for two months and 184 useable data was collected after screening, which represents a $37 \%$ response rate. 


\subsection{Measurement}

The entire variables and items used in the current research were adapted from previous studies. A five-point Likert-scale was employed to measure the items of the present study ranging from strongly disagree (1) to strongly agree (5) for all the variables. The 15 items for measuring tax evasion were adapted from Gilligan and Richardson (2005). Reverse coding was used for item 5 in the current study, in order to increase the internal validity (Efebera et al., 2004) and this was not applied in the original study by Gilligan and Richardson (2005). Probability of detection was measured by 3 items and were adapted from Efebera et al. (2004) and tax penalty with 4 items were adapted from James et al. (2005). Tax rate was measured by 3 items which were adapted from Abdul Jabbar (2009).

\section{PLS Data Analysis and Results}

In analysing the research model, the Partial Least Squares (PLS) analysis technique was applied by using Smart PLS 3 software. The measurement model (the relationship between variable and indicators) was analysed using a two stage analytical models as recommended by Anderson and Gerbing (1988), the method was also employed in testing the structural model (relationships between the variables) for the current study (Hair et al., 2017).

\subsection{Assessment of Measurement Model}

The measurement model is evaluated using 2 measures of validity; the convergent and discriminant validity. The convergent validity is assessed analysing the indicators loadings, average variance extracted (AVE) and composite reliability. As shown in Table 1 below, the indicator loading for all the items is above the minimum threshold of 0.50 . The values range from 0.651 to 0.915 , the AVE values ranged from 0.501 to 0.798 and they were also above the recommended value of 0.50 , while the composite reliability values also ranged from 0.850 to 0.940 which are also above the recommended value of 0.70 (Hair et al., 2017). Nevertheless, item numbers 7, 10, 15 for tax evasion were deleted as a result of low indicator loadings. Conclusively, based on the outcome, the current study is said to have an acceptable convergent validity.

Table 1. Convergent validity

\begin{tabular}{|c|c|c|c|c|}
\hline Variables & Items & Loading & CR & AVE \\
\hline \multirow[t]{12}{*}{ Tax Evasion } & TE1 & 0.725 & 0.923 & 0.501 \\
\hline & TE2 & 0.742 & & \\
\hline & TE3 & 0.748 & & \\
\hline & TE4 & 0.753 & & \\
\hline & TE5 & 0.706 & & \\
\hline & TE6 & 0.651 & & \\
\hline & TE8 & 0.712 & & \\
\hline & TE9 & 0.695 & & \\
\hline & TE11 & 0.670 & & \\
\hline & TE12 & 0.702 & & \\
\hline & TE13 & 0.703 & & \\
\hline & TE14 & 0.667 & & \\
\hline \multirow[t]{3}{*}{ Probability of Detection } & POD1 & 0.895 & 0.908 & 0.766 \\
\hline & POD2 & 0.814 & & \\
\hline & POD3 & 0.915 & & \\
\hline \multirow[t]{4}{*}{ Tax Penalty } & TP1 & 0.911 & 0.940 & 0.798 \\
\hline & TP2 & 0.879 & & \\
\hline & TP3 & 0.889 & & \\
\hline & TP4 & 0.893 & & \\
\hline \multirow[t]{3}{*}{ Tax Rate } & TR1 & 0.821 & 0.850 & 0.654 \\
\hline & TR2 & 0.790 & & \\
\hline & TR3 & 0.815 & & \\
\hline
\end{tabular}


Following the establishment of the convergent validity, the next step was the examination of the discriminant validity following Hair et al. (2017) criterion. This involved comparing the AVE's square root values with those of the correlations of the latent variable. As indicated in Table 2, the result showed that all the square root of AVE's are higher in all cases, as were the diagonal values in the respective rows and columns. This shows that the adequate discriminant validity is obtained. In general, the outcome of the validity tests for the measurement model of the study were found to be satisfactory for both convergent and discriminant validity.

Table 2. Discriminant Validity Analysis

\begin{tabular}{lcccc}
\hline \multicolumn{1}{c}{ Variables } & TE & POD & TP & TR \\
\hline Tax Evasion (TE) & $\mathbf{0 . 7 0 7}$ & & & \\
Probability of Detection (POD) & -0.294 & $\mathbf{0 . 8 7 5}$ & & \\
Tax Penalty (TP) & -0.222 & 0.104 & $\mathbf{0 . 8 9 3}$ & \\
Tax Rate (TR) & 0.320 & -0.180 & -0.155 & $\mathbf{0 . 8 0 9}$ \\
\hline
\end{tabular}

\subsection{Assessment of Structural Model}

The predictive strength of the research model estimated using R-square $\left(R^{2}\right)$ (coefficient of determination) value explains the joint effect of exogenous and endogenous variables (Hair et al., 2017). The Smart PLS algorithm function was employed to measure the $R^{2}$ value, which is the amount of variance accounted for by the exogenous variables (Hair et al., 2017). The three variables had an $R^{2}$ value of 0.184 implying that $18.4 \%$ of the variation in the income tax evasion is accounted for by probability of detection, tax penalty and tax rate.

Bootstrapping function was applied with 5,000 re-sampling from 184 cases in order to examine the significance of the path coefficients $(\beta)$ using a one-tailed test. Accordingly, the path estimates and $t$-values were measured for all the hypothesized relationships in the present study. Table 3 , depicts the analysis outcome of the structural model. The outcome showed that the probability of detection $(\beta=-0.232 ; \mathrm{t}=$ 3.166; $p=0.001)$ along with tax penalty $(\beta=-0.158 ; t=2.494 ; p=0.006)$ are negatively associated with tax evasion, this affirms $\mathrm{H} 1, \mathrm{H} 2$ hypotheses. Furthermore with a significant and positive influence of tax rate on tax evasion, $\mathrm{H} 3$ is also supported $(\beta=0.253 ; t=3.455 ; p=0.000)$.

Table 3. Results of Hypotheses Testing

\begin{tabular}{lcccc}
\hline Hypothesis: Path & Path Coefficient & T-Statistics & P-Value & Decision \\
\hline $\mathrm{H}_{1}$ : Probability of Detection -> Tax Evasion & -0.232 & 3.166 & $0.001^{* *}$ & Supported \\
$\mathrm{H}_{2:}$ Tax Penalty -> Tax Evasion & -0.158 & 2.494 & $0.006^{* *}$ & Supported \\
$\mathrm{H}_{3}$ : Tax Rate -> Tax Evasion & 0.253 & 3.455 & $0.000^{* *}$ & Supported \\
\hline
\end{tabular}

Note: Significant at ${ }^{* *} \mathrm{p}<0.01,{ }^{*} \mathrm{p}<0.05$.

\subsection{Predictive Relevance}

Other than the $R^{2}$ value, another important statistic value is the Predictive relevance $\left(Q^{2}\right)$ which is a resampling technique (Henseler et al., 2009). To examine the predictive relevance of the endogenous variable, the blindfolding technique was applied with the multiple or single item in reflective measurement model (Hair et al., 2017). In accordance with Hair et al. (2017) and Henseler et al. (2009), a cross-validated redundancy measure $Q^{2}$ value which is greater than zero implies the predictive relevance of the model. The outcome of this test showed that the present study's model has predictive relevance for endogenous variable as presented in Table 4.

Table 4. Variable Cross-Validated Redundancy $\left(\mathrm{Q}^{2}\right)$

\begin{tabular}{lccc}
\hline Endogenous latent variable & SSO & SSE & 1-SSE/SSO \\
\hline Tax Evasion & $2,208.000$ & $2,035.322$ & 0.078 \\
\hline
\end{tabular}




\section{Discussions}

The study set out with the objective of assessing the influence of probability of detection, tax penalty and tax rate on income tax evasion by SMEs owners/managers. The probability of detection is known to be an important deterrent of tax evasion (Park and Hyun, 2003). The present study showed probability of detection significantly and negatively related to income tax evasion. The current study has shown that the probability of detection has a significantly negative relationship with income tax evasion. The findings of the current study are in agreement with those of other existing empirical literature that also affirmed the significant and negative influence of probability of detection on tax evasion (Abdul-Jabbar, 2009; Almunia and Lopez-Rodriguez, 2018; Ayuba et al., 2016; Bott et al., 2017). This result can be attributed to the fact that taxpayers react based on the perception that previous year increase in the sample of businesses audited by tax authority could increase the detection of irregularities in the current year audit. In addition, taxpayers might weigh the consequence of being audited and penalized due to tax evasion against compliance. Thus, resulting into higher income been reported by the taxpayers.

The threat of tax penalties is considered as an important tool for discouraging tax evasion (Feld and Frey, 2006). Accordingly, the current study found that tax penalties have a negative significant effect on income tax evasion. Therefore, the result indicates the crucial role that tax penalty plays in influencing the decision of SMEs with regards to income tax evasion. Also, the result is consistent with findings of some previous studies related to tax penalty and tax evasion (Chau and Leung, 2009; Feld and Frey, 2006; Hasseldine et al., 2007). This negative outcome can be attributed to the fact that owners/managers of SMEs behave in a rational manner. Since owners/managers are guided by the goal of maximizing the expected utility from a tax evasion gamble, they compare the benefits for successful tax evasion with the penalty if caught. Thus, SMEs resort to pay taxes as a result of the fear of punishment for income tax evasion.

The tax rate is a vital factor which determines taxpayers' perceived fairness and equity of the entire tax system (Devos, 2007). Tax rate is considered as a measure of the perception of fairness of the tax rate structure and burden distribution (Gilligan and Richardson, 2005). The result of the current study supports the hypothesis that suggested a positive relationship between tax rate and income tax evasion. The result of the present study is consistent with most of the earlier studies that also found a significantly positive effect of tax rate on tax evasion (Dlamini, 2017; Freire-Seren and Panades, 2013; Ottone et al., 2018; Rahhal, 2017). The present outcome established that the SMEs have a perception that structure of the tax rate is unfair, thereby motivating tax evasion. This finding could be justified by the existing tax rate for large companies' in Palestine which is fixed at $15 \%$ of taxable profit for a long time. SMEs perceives this to be unfair, they think that the larger companies should possess a higher ability to pay income tax, so they are expected to pay a higher rate than SMEs.

\section{Implications}

The present study is of huge significance in guiding the tax authority towards reducing tax evasion among SMEs taxpayers. They make up a vital part of taxpayers in Palestine. Decreasing tax evasion will facilitate Palestinian government to decrease the government's budget deficit and also accomplish fiscal sustainability in Palestine. Therefore, the present study recommends that probability of detection, tax penalty and tax rate should be targeted by tax administration in the attempt to measure income tax evasion considering their predictive strength. SMEs are most likely to comply when they consider that the risk of tax evasion is higher than paying taxes legally. It is also recommended that tax authority should consider more frequent operational inspections of SMEs alongside enhanced tax auditor efficiency and friendly remediation. This implies that the scope of audit coverage by tax authority needs to be expanded and training provided for tax auditors with respect to the detection of defaulting SMEs involved in income tax evasion. Adopting these recommendations will assist in revealing many tax evaders. Furthermore, a more adequate sanction is required to be imposed by the tax authority. SMEs that are resolute income tax evaders should be charged, adequately fined and forced to pay the outstanding tax with interest. This approach will encourage SMEs owners/managers to pay the income taxes by the due date. SMEs taxpayers 
perceive the present tax rate as unfair. A decrease in the tax rate will increase their income; therefore, they achieve more profits that can be used to finance their growth and expansion. Thus, Palestinian tax authority needs consideration of the above mentioned issue to have a fair tax rate for SMEs to enhance their capacity to pay taxes in the future.

\section{Limitations and Future Research}

Even though the present study contributed to literature by examining some major determinants of income tax evasion, some limitations exist. The main limitation arises from the use of structured questionnaires, as it does not represent the honest answers of importers or actual behaviour. Hence, a mix method technique is recommended. It involves combining a survey with other forms of qualitative techniques that includes case studies and interviews to offer deeper insights and more reliable support concerning the findings. Thus, future studies may advance the present study by introducing new determinants in addition to the significant determinants in the current research. Future research can also consider extending the model to include other unproven factors from socio-psychological factors.

\section{Conclusions}

The Palestinian government relies on taxation as one of its sustainable sources of revenue. However, the challenge of tax evasion curtailed the ability of the government to maximize expected revenue generation from taxation in order to finance developmental projects. The present study is concerned with the income tax of SMEs taxpayers, which represents an important part of taxpayers in Palestine. SMEs have the potential of a high source of tax revenue generation; but are hindered by a high level of tax evasion. Reducing tax evasion by SMEs will help to raise the value of revenue generation by the government. In general, the findings of the current research revealed that the probability of detection and tax penalties are negatively associated with income tax evasion, while, tax rate is positively associated with income tax evasion. However, the present study observed that an existence of effective deterrence can encourage taxpayer's compliance, especially if the risk of detection of evasion is higher than paying taxes. Hence, it is suggested that the tax authority should widen their sample of audited taxpayers alongside imposing tough tax penalties as a valuable policy aimed at discouraging tax evasion. Furthermore, taxpayers perceive the present tax rate as unfair, hence demanding a preference for a progressive tax rate structure. The findings of the present study offer a better comprehension of the determinants of income tax evasion. Particularly in strategic planning associated with tax structure confronted with the challenge of declining income tax revenue.

\section{References}

1. Abdixhiku, L. (2013). Determinants of business tax evasion in transition economies. (Unpublished doctoral dissertation). Staffordshire University, England.

2. Abdul-Jabbar, H. (2009). Income tax non-compliance of small and medium enterprises in Malaysia: Determinants and tax compliance costs. (Unpublished doctoral dissertation). Curtin University of Technology, Perth, Australia.

3. Adebisi, J. F., \& Gbegi, D. O. (2013). Effect of tax avoidance and tax evasion on personal income tax administration in Nigeria. American Journal of Humanities and Social Sciences, 1(3), 125-134.

4. Ali, M. M., Cecil, H. W., \& Knoblett, J. A. (2001). The effects of tax rates and enforcement policies on taxpayer compliance: A study of self-employed taxpayers. Atlantic Economic Journal, 29(2), 186-202.

5. Alkhatib, A, A., \& Abdul-Jabbar, H. (2017). An Economic Framework for Tax Evasion in Palestine. American-Eurasian Journal of Scientific Research, 12(6), 300-304.

6. Allingham, M., \& Sandmo, A. (1972). Income tax evasion: A theoretical analysis. Journal of Public Economics, 1(3-4), 323-338.

7. Alm, J., Martinez-Vazquez, J., \& McClellan, C. (2016). Corruption and firm tax evasion. Journal of Economic Behaviour \& Organization, 124, 146-163. 
8. Alm, J., \& McKee, M. (2006). Audit certainty, audit productivity and taxpayers' compliance. National Tax Journal, 59(4), 801-816.

9. Almunia, M., \& Lopez-Rodriguez, D. (2018). Under the radar: The effects of monitoring firms on tax compliance. American Economic Journal: Economic Policy, 10(1), 1-38.

10.Anderson, J. C., \& Gerbing, D. W. (1988). Structural equation modelling in practice: A review and recommended two-step approach. Psychological Bulletin, 103(3), 411-423.

11.Ariel, B. (2012). Deterrence and moral persuasion effects on corporate tax compliance: Findings from a randomized controlled trial. American Society of Criminology, 50(1), 27-69.

12. Ayers, B. C., Seidman, J. K., \& Towery, E. M. (2015). Taxpayer behaviour under audit certainty. Paper presented at IRS-TPC Research Conference. University of Georgia, Athens, USA.

13. Ayuba, A., Saad, N., \& Ariffin, Z. Z. (2016). Perceived service orientation, economic factors, psychological factors and tax compliance: Evidence from Nigerian SMEs. Malaysian Management Journal, 20, 41-57.

14. Bishara, S. (2015, June 9). The percentage of tax evasion in Palestine up to $70 \%$ (in Arabic). Aliqtisadi. Retrieved from http://www.aliqtisadi.ps/ar_page.php? id=35c736 y3524406 Y35c736.

15. Bott, K. M., Cappelen, A. W., Sorensen, E., \& Tungodden, B. (2017). You've got mail: A randomised field experiment on tax evasion. (Working Paper No. 10/2017). Norwegian School of Economics, Bergen, Norway.

16. Chau, G., \& Leung, P. (2009). A critical review of Fischer tax compliance model: A research synthesis. Journal of Accounting and Taxation, 1(2), 34-40.

17. Coalition for Accountability and Integrity. (2018, April 23). USD 500 million losses of tax evasion in Palestine (in Arabic). Life Press. Retrieved from http://www.hayatweb.com/ breaking/143106

18. Devos, K. (2007). Measuring and analysing deterrence in taxpayer compliance research. Journal of Australian Taxation, 10(2), 182-219.

19. Dlamini, B. (2017). Determinants of tax non-compliance among small and medium enterprises in Zimbabwe. Journal of Economics and Behavioural Studies, 9(4), 242-250.

20. Efebera, H. D., Hayes, C., Hunton, J. E., \& O'Neil, C. (2004). Tax compliance intentions of lowincome individual taxpayers. Advances in Accounting Behavioural Research, 7, 1-25.

21. Fallah, B. (2014). The pros and cons of formalizing informal MSES in the Palestinian economy. (Working Paper, No. 893). The Economic Research Forum, Palestine.

22. Feld, L. P., \& Frey, B. (2006). Tax evasion in Switzerland: The role of deterrence and tax morale. (Working Paper, No. 284). Institute for Empirical Research in Economics, University of Zurich, Switzerland.

23. Fjeldstad, O. H., \& Semboja, J. (2001). Why people pay taxes: The case of the development levy in Tanzania. World Development, 29(12), 2059-2074.

24. Franzoni, L. A. (2000). Tax evasion and tax compliance. The Economics of Public and Tax Law, $4(1), 52-94$.

25. Freire-Seren, M. J., \& Panades, J. (2013). Do higher tax rates encourage/discourage tax compliance? Modern Economy, 4(12), 809-817.

26. Gilligan, G., \& Richardson, G. (2005). Perceptions of tax fairness and tax compliance in Australia and Hong Kong: A preliminary study. Journal of Financial Crime, 12(4), 331-343.

27. Guldana, B. K. (2013). Tax evasion: Criminological characteristic, problems of criminal liability application and improvement of the mechanism of crime suppression. Middle-East Journal of Scientific Research, 16(7), 907-912.

28. Hair, J. F., Hult, G. T. M., Ringle, C., \& Sarstedt, M. (2017). A primer on partial least squares structural equation modeling (PLS-SEM) (2nd ed.). New York, USA: SAGE Publications.

29. Hasseldine, J., Hite, P., James, S., \& Toumi, M. (2007). Persuasive communications: Tax compliance enforcement strategies for sole proprietors. Contemporary Accounting Research, 24(1), 171194.

30. Henseler, J., Ringle, C. M., \& Sinkovics, R. R. (2009). The use of partial least squares path modelling in international marketing. Advances in International Marketing, 20(1), 277-319.

31. James, S., Murphy, K., \& Reinhart, M. (2005). Taxpayer beliefs and views: Two new surveys. Australian Tax Forum, 20(2), 157-188. 
32. Kira, A. R. (2017). An evaluation of government's initiatives in enhancing small taxpayers' voluntary tax compliance in developing countries. International Journal of Academic Research in Accounting, Finance and Management Sciences, 7(1), 253-267.

33. Kirchler, E. (2007). The economic psychology of tax behaviour. Cambridge, United Kingdom: Cambridge University Press.

34. Malkawi, B. H., \& Haloush, H. A. (2008). The case of income tax evasion in Jordan: Symptoms and solutions. Journal of Financial Crime, 15(3), 282-294.

35. Mansor, M., \& Gurama, Z. (2016). The determinants of tax evasion in gombe state Nigeria. International Journal of Economics and Financial Issues, 6(7S), 165-170.

36. Martinez-Vazquez, J., \& Rider, M. (2005). Multiple model of tax evasion: Theory and evidence. National Tax Journal, 58(2), 286-316.

37. McGee, R. W., Ho, S. S. M., \& Li, A. Y. S. (2008). A comparative study on perceived ethics of tax evasion: H7ong Kong vs the United States. Journal of Business Ethics, 77(2), 147-158.

38. Nzaro, R., Hove, N., Mhazo, S., Mudzura, M., Runyowa, L., Onias, Z., \& Muropa, B. C. (2013). An investigation on effective strategies to curb tax evasion: A survey of Beitbridge ZIMRA staff and clients, Zimbabwe. Elite Research Journal of Accounting and Business Management, 1(1), 1-9.

39. Okauru, I. O. (2012). Comprehensive tax history of Nigeria. Ibadan, Nigeria: Safari Books Ltd.

40. Oladipupo, A. O., \& Obazee, U. (2016). Tax knowledge, penalties and tax compliance in small and medium scale enterprises in Nigeria. IBusiness, 8(1), 1-9.

41. Olowookere, J. K., \& Fasina, H. T. (2013). Taxpayers' education: A key strategy in achieving voluntary compliance in Lagos State, Nigeria. European Journal of Business and Management, 5(10), 146155.

42. Ottone, S., Ponzano, F., \& Andrighetto, G. (2018). Tax compliance under different institutional settings in Italy and Sweden: An experimental analysis. Economic Political, 35(2), 367-402.

43. Park, C. G., \& Hyun, J. K. (2003). Examining the determinants of tax compliance by experimental data: A case of Korea. Journal of Policy Modelling, 25(8), 673-684.

44. Rahhal, A. I. (2017). Effectiveness of Palestinian income tax rates in facing tax evasion. Global Journal of Engineering Science and Research Management, 4(1), 8-14.

45. Sabri, N. R. (2010). MSMEs in Palestine; challenges and potential (Palestine Economic Policy Research Institute). Ramallah, Palestine. Retrieved from http://www.palestineeconomy.ps/files/server/ 20152501091 809-1.pdf

46. Schneider, F., \& Enste, D. (2000). Shadow economies : Size, causes, and consequences. Journal of Economic Literature, 38(1), 77-114.

47. Slemrod, J., Blumenthal, M., \& Christian, K. W. (2001). Taxpayer response to increased probability of audit: Evidence from a controlled experiment in Minnesota. Journal of Public Economic, 79(3), 455-483.

48. Tanzi, V., \& Zee, H. H. (2001). Tax policy for developing countries. Washington, USA: International Monetary Fund.

49. Torgler, B. (2005). Tax morale in Latin America. Public Choice, 122(1/2), 133-157. 